\title{
Do padre Vieira da história oficial à personagem de Ana Miranda em Boca do Inferno
}

\author{
Édila de Cássia Souza Santana \\ Universidade Federal de Mato Grosso do Sul (UFMS), Três Lagoas, Mato Grosso do Sul, Brasil \\ kassiaedila@yahoo.com.br
}

DOI: http://dx.doi.org/10.21165/el.v46i3.1593

\begin{abstract}
Resumo
Neste artigo analisamos os aspectos que configuram a formação da personagem António Vieira em Boca do Inferno, de Ana Miranda. Com base na historiografia literária e a fim de estabelecermos as semelhanças e as diferenças que interagem no contexto romanesco, investigamos os mecanismos utilizados para a construção da personagem no romance de Miranda, para caracterizar a representação de Vieira.
\end{abstract}

Palavras-chave: metaficção historiográfica; literatura portuguesa; António Vieira.

From the priest Vieira of the official history to the character of Ana Miranda in Boca do Inferno

\begin{abstract}
In this study, we analyze the aspects that configure the formation of the character Antonio Vieira in the book Boca do Inferno [Hell's Mouth], by Ana Miranda. Based on the literary historiography, and in order to stablish the similarities and differences interacting in the romantic context, we investigate the mechanisms employed to build the character in Miranda's romance to characterize the representation of Vieira.
\end{abstract}

Keywords: historiographical metafiction; portuguese literature; Antonio Vieira.

\section{Introdução}

Sabemos que a discussão acerca das relações entre a literatura e a história já proliferou inúmeros trabalhos acadêmicos, num amplo campo de indagações, sendo objeto de estudo de vários críticos e teóricos, que a têm abordado em suas obras, devido às suas correlações e divergências.

No que pauta esta discussão, percebemos que ela se refere aos inúmeros diálogos que envolvem o discurso ficcional e o discurso histórico desde as prédicas aristotélicas na Poética. Partindo dos conceitos ora sistematizados de cada discurso, há um posicionamento claro e ao mesmo tempo bem diverso que, ao longo da história, veio se modificando, de forma que a cada notificação feita em relação a cada discurso novos questionamentos surgem, em razão dos mecanismos que envolvem cada um desses campos discursivos que ora se aproxima, ora se distancia.

Diante disso, não podemos negar que o passado sempre se fez presente em nossa memória, seja por meio da história, seja por meio da ficção. É através de seus percursos que conhecemos o passado, que gerou a história e contribuiu para sua formação. Seja pela narrativa histórica, ou a narrativa ficcional, apreendemos e correlacionamos as projeções 
que deram o ponto de partida para ambas as narrativas: tanto a história quanto a narrativa de ficção são formas de conhecimento do mundo de seu tempo.

\section{O discurso histórico e o discurso literário: correlações e divergências}

A discussão neste contexto, tão íntima e ao mesmo tempo dispersa, ocorre em razão da velha distinção entre ficção e história como duas formas distintas de narrar o passado. A história, definida como narração metódica dos acontecimentos, como representação do verdadeiro, e a ficção como a arte de fingir, como representação do imaginável, são duas perspectivas, dois nortes sobre os quais se pautam inúmeras discussões, convergindo para um único ponto: narrar o passado.

Antônio Roberto Esteves, em sua obra $O$ romance histórico brasileiro contemporâneo (1975-2000), confirma essa ideia, salientando que a literatura e a história sempre caminharam lado a lado, até mesmo quando pareciam distantes. O estudioso aponta que "[...] a partir da segunda metade do século XX, é quase consenso generalizado que a história e a literatura têm algo em comum: ambas são constituídas de material discursivo, permeado pela organização subjetiva da realidade feita por cada falante". (ESTEVES, 2010, p. 17). Nesse sentido, os textos históricos assim como os ficcionais, assemelham-se, pois ambos penetram no mundo da linguagem que é rico em significados. A ideia de Esteves, ao discutir essa relação, caminha no sentido de mostrar que o século $\mathrm{XX}$ em termos de revolução metodológica contribuiu também para deixar a escrita da história mais complexa e desafiadora pela escolha de novos objetos e a sua relação com diferentes áreas do conhecimento, inclusive com a literatura.

No que pauta os discursos ora em discussão, a narrativa histórica e a ficcional em dado momento se encontram, interagindo e entrosando-se como formas de linguagem. Ambas têm na atividade humana seu objeto e na comunicação sua forma de expressão. Tanto a história quanto a ficção são representações de identidades que incorporam discursos e aspectos próprios do e no seu processo formativo. Um historiador narra fatos verídicos da história, com os mecanismos próprios do material histórico e com a visão que tem do mundo e do homem, assim como o ficcionista constrói sua trama de acordo com a sua concepção do homem e da história, que por sua vez é determinada por signos culturais, com aspectos próprios do campo da ficção. Ambas falam da realidade, registram a vida humana e suas experiências, porém, são construções que se distinguem pelo compromisso e a forma com que lidam com a realidade.

Lukács (2011, p. 35) afirma que os grandes momentos históricos de crise favoreceram o surgimento de uma reflexão sobre os sentidos da história. Isso nos permite entender a atmosfera em que o rótulo "romance histórico" se concentra e compreender o que o diálogo entre ficção e história pode promover. Linda Huctheon criou o termo "metaficção historiográfica" em função desse diálogo. De acordo com a autora, a metaficção historiográfica pode ser vista como um texto que se apropria de acontecimentos e personagens históricos, incorporando história e ficção" (HUTCHEON, 1991, p. 21). Essa nova forma de relacionar o discurso histórico ao discurso ficcional permite uma proposição na modalidade relacional história/literatura, pois, a partir da concepção da existência de uma metaficção historiográfica, os discursos de ambas unemse em função do propósito que gravita em torno das produções escritas, ficcionais ou não, levando os leitores à autorreflexão, ao questionamento, uma vez que ambas são processadas a partir dos mecanismos que a linguagem oferece. 
Marilene Weinhardt, em seu artigo Considerações sobre o Romance Histórico, afirma que "[...] ao romance histórico não interessa repetir o relato dos grandes acontecimentos, mas ressuscitar poeticamente os seres humanos que viveram essa experiência" (WEINHARDT, 1994, p. 51). Assim, o romance histórico permite ao leitor apreender as razões sociais e humanas que fazem com que homens de outros tempos e espaços pensassem, sentissem e agissem da forma como o fizeram.

Diante dessa variabilidade e da dimensão que o assunto atinge, resta-nos a consciência em apontar para cada campo com os instrumentos necessários, visto que se trata, apesar das semelhanças de alguns interesses que as permeiam, de esferas distintas tanto em suas estruturas como também em suas funcionalidades. É importante ressaltar que as recentes leituras críticas da história e da ficção têm se concentrado mais naquilo que as duas formas de escrita têm em comum do que em suas diferenças.

O romance histórico Boca do Inferno, publicado em 1989 pela escritora Ana Miranda, narra a história da Bahia colonial durante o governo tirânico do militar Antônio de Souza de Menezes, apelidado de Braço de Prata. A narrativa gira em torno do assassinato de Francisco Teles de Menezes, secretário do governador da Bahia, o que insufla uma perseguição aos supostos culpados, entre eles, Gregório de Matos e o padre António Vieira. "[...] a narrativa traz acontecimentos de suas vidas, mas especialmente sua forma de ver o mundo" (ESTEVES, 2010, p. 128).

Ana Miranda usa o assassinato do alcaide-mor Francisco de Teles de Menezes, um fato histórico ocorrido na Bahia colonial do século XVII, para desenvolver a ação do romance, que envolve personagens históricas importantes no contexto da época. A autora incorpora ainda a luta política entre os Menezes, aliado ao governador-geral, e os Ravascos, aliados de Bernardo Ravasco, irmão do padre Vieira e secretário do governogeral, fato que ajuda a (re) construir com intensidade o ambiente político e cultural da primeira capital do Brasil.

\section{Padre António Vieira: o ser histórico, o ser palavra e o ser personagem}

Considerado um dos homens mais notáveis da história de Portugal e do Brasil, e também um dos mestres da língua portuguesa, um dos primeiros pregadores do seu tempo, homem de inteligência vastíssima, que dominava inúmeros assuntos e mobilizava com eloquência os diferentes cenários do seu tempo, está o Padre António Vieira. Nasceu em Lisboa em 6 de fevereiro de 1608, filho de um modesto casal, Cristovão Vieira Ravasco, fidalgo de nobre ascendência, e Maria de Azevedo.

Vieira é considerado como um dos mais vigorosos sermonistas do Barroco e o primeiro intelectual literário de vulto internacional das letras do Brasil. Sua participação em diversos segmentos e com expressões veementes diante de problemas candentes de sua época não se limitou ao incentivo à tomada de posições, mas também ao engajamento direto nas causas, sofrendo, em razão de suas opiniões e ações, perseguições. Ele interagiu e rompeu com as margens dos conflitos que afloravam.

José van den Besselar pondera que a vida de Vieira é um romance que vale a pena contar. 
Numa carta dirigida a um confrade, em 1658, António Vieira resumia as vicissitudes da sua vida nestes termos: 'Não há maior comédia que a minha vida; e quando quero ou chorar ou rir, ou admirar-me ou dar graças a Deus ou zombar do mundo, não tenho mais que olhar para mim' (Cartas, III, 718) (BESSELAR, 1981, p. 8).

Vieira representava no alcance de suas medidas e de seu repertório, o mundo, no sentido permitido pelo contex to em que estava inserido. Jesuíta profundamente engajado nas causas da colonização do Brasil, defendeu com veemência as grandes causas metropolitanas. Segundo Merquior (1996, p. 30),

Vieira levou, na quinta década do século, uma existência brilhante e movimentada: tribuno da revolta contra a ocupação holandesa do Brasil, porta-voz da colônia na corte de Lisboa, pregador da Capela Real, mentor da Restauração bragantina, embaixador junto à monarquia francesa, ao governo holandês e à Santa Sé, adversário temido da Inquisição.

Não se limitou à luta pela catequese dos índios brasileiros, especialmente os maranhenses. Por essa e outras razões, Vieira é considerado um importante representante das atividades missionárias no Brasil. Uma de suas ações de impacto foi quando chefiou a missão jesuítica no Maranhão, entre 1652 e o final de 1661, decisiva para a promulgação da "Lei da Liberdade dos Índios". Seu trabalho no Maranhão com os índios, de acordo com Besselar, rendeu-lhe a fama de "Pai Grande" dos indígenas.

Ainda segundo Besselar (1981, p. 36):

[Vieira] Dirigia os trabalhos dos confrades, na sua qualidade de superior. Fazia extensas e incómodas viagens pelo rio Amazonas para visitar as aldeias, onde baptizava, confessava e dirigia as cerimônias religiosas. Aprendia os idiomas das diversas tribos índias, tornando-se capaz de escrever um conciso catecismo em seis línguas diferentes.

Suas histórias à frente das atividades missionárias no Brasil serviram de conteúdo para muitos. Graças à notoriedade de seus trabalhos, as missões jesuíticas mudaram a sua história e a de todos os nela envolvidos. Nomes como José Lúcio de Azevedo, Barredo, Azevedo e Kiemam utilizaram as cartas e outros documentos de Vieira como obras fundamentais para os estudos vieirianos ${ }^{2}$. O Padre Serafim Leite também abordou de forma coesiva a obra de Vieira, porém, de acordo com António José Saraiva, deixou algumas lacunas, "[...] esquecendo factos indispensáveis para que se siga o fio dos acontecimentos" (SARAIVA, 1992, p. 13). Todo enfoque em volta dessa questão poderia passar despercebido se não atentássemos para a realidade do contexto que envolveu esse problema.

Saraiva (1992) afirma ainda que a vida de António Vieira é uma realidade a se conhecer; a própria personagem não é um dado que esteja definitivamente conhecido. Daí a dinâmica e a relevância de falar a respeito de Vieira levando em consideração a sua capacidade intelectual, sobretudo o poder concentrado em suas ideias que após mais de 300 anos de sua morte continuam sendo um pensamento de enormes repercurssões.

\footnotetext{
${ }^{1}$ A Lei da Liberdade dos Índios proibia qualquer guerra ofensiva contra eles sem a autorização prévia do rei. As aldeias eram dirigidas diretamente pelos jesuítas, inclusive no que dizia respeito às atividades temporais. (MURARO, 2003, p. 188).

${ }^{2}$ Berredo era Bernardo Pereira de Berredo e Castro, historiador e administrador colonial português.
} 
O seu reconhecimento e o seu talento na arte retórica fazem jus à funcionalidade dos seus sermões. Com eles, Vieira divulgava a fé cristã e pensava sobre os problemas relacionados à ganância, à injustiça, à corrupção e à política secular. Orlando Neves ressalta que "Nos numerosos sermões desta época da sua vida, Vieira não se cansava de animar o auditório a perseverar na luta desigual com Castela e propunha medidas concretas para a solução de problemas, inclusive de ordem econômica" (NEVES, 2010, p. 28).

O grande número de sermões deixados por Vieira, diante de um olhar superficial, ganharia apenas a fama de ser mais um no índice de produções e discursos desse orador barroco. Porém, a análise do contexto em que nasceram e a eloquência no conteúdo de cada um deles, junto com sua funcionalidade, a projeção de seus resultados e, acima de tudo, da arte retórica de quem os propagou, dão a medida da projeção de Vieira para além de seu tempo.

Digno de referência é que o sermonário de Vieira destaca-se não somente pelas ideias propagadas, o que por si já é relevante, mas também por conta do efeito dessas ideias no período em que foram divulgadas. A conversão delas em argumentos teológicos, relacionados com passagens bíblicas, episódios do Antigo e Novo Testamento, e acontecimentos históricos, expressa a coexistência de um conhecimento parenético ${ }^{3}$ que elucidava seus discursos.

Os sermões de Vieira examinam assuntos que tocam a teologia, as organizações política e social, a moral, a ética, a religião católica e as outras religiões, enfim, uma série de questões que colocam suas obras no patamar que não se restringe à atividade de pregador de Vieira, mas que também se volta para o século em que viveu, quase que por inteiro.

Vieira firma essa intervenção dos sermões na concepção de valores e na tentativa de resolução dos conflitos. Assim nesse segmento, diante dos vários acontecimentos na colônia, a exemplo da invasão dos holandeses em 1640 a terras brasileiras, ele não ficou neutro, descrevendo a situação, denunciando o ocorrido às autoridades portuguesas, aos seus correspondentes na Europa, bem como ao Padre Geral em Roma.

Eram as forças heréticas e diabólicas descarregadas do inferno pelo Holandês; era a guerra santa que Portugal - o 'povo eleito' dos tempos modernos — tinha de fazer contra os inimigos de Deus. E por que razão permitia Deus essa calamidade? Para punir os pecados dos Portugueses, pois que estes, repetindo a história de Israel, se mostravam indignos da protecção divina. (BESSELAR, 1981, p. 11).

Esse mesmo contexto rendeu a Vieira o Sermão pelo Bom Sucesso das Armas de Portugal contra as da Holanda, pregado na Igreja de Nossa Senhora da Ajuda, da cidade de Salvador, com o Santíssimo Sacramento exposto. Quando os holandeses ameaçaram invadir pela segunda vez as terras brasileiras, foram feitas, durante quinze dias, contínuas preces, sendo esse sermão de Vieira o último pregado, como fecho das orações.

\footnotetext{
3 "Quanto à eloquência religiosa, também chamada parenética, discute os dogmas da religião com vistas a incuti-los no ouvinte, e classifica-se em sermão ou prédica [...]; homilia [...]; panegírico e oração fúnebre" (MOISÉS, 1988, p. 378).
} 
Esta é Todo-Poderoso e Todo-Misericordioso Deus, esta é a traça de que usou para render vossa piedade, quem tanto se conformava com vosso coração. E desta usarei eu também hoje, pois o estado em que nos vemos, mais é o mesmo que semelhante. Não heis de pregar hoje ao povo, não heis de falar com os homens; mais alto hão de sair as minhas palavras ou as minhas vozes: a vosso peito divino se há de dirigir todo o sermão. [...] Tão presumido venho da vossa misericórdia, Deus meu, que ainda que nós somos os pecadores, vós haveis de ser o arrependido. (VIEIRA, 1968, p. 19)

A sua fama de orador sacro cresceu, assim como cresceu o impacto de seus questionamentos relacionados aos problemas do Brasil colônia, com destaque para os da Bahia. De acordo com Orlando Neves, "Vieira deixou claro que a sua actividade não se limitaria a ser meramente religiosa, pois os preceitos jesuíticos, que apontavam para a emulação e o instinto de luta, levavam-no a bater-se pela justiça" (NEVES, 2010, p. 27).

No Sermão do Bom Ladrão, encontramos essas especificações do que era Vieira. Nesse sermão ele discute os pilares de suas concepções sobre ética e poder na política, em consonância com suas mediações marcadas e estabelecidas na dinâmica do século XVII. Sua concepção pode ser proveitosa em contextos afins na contemporaneidade, uma vez que possibilita o questionamento da atualidade, em face das situações caóticas que permeiam a política brasileira. No entanto, sua visão política e ética é organizada em função de um contexto histórico, político e cultural do Brasil colônia regido por um sistema escravocrata e suas limitações. Embora os problemas que permeiam a política prevaleçam, como a corrupção, o olhar seguido nas especificações de Vieira parte de um contexto que compreende a dinâmica social e política envolvida, podendo ser exprimido apenas por quem tinha profundo conhecimento de sua época.

O Sermão do Bom Ladrão foi pronunciado pela primeira vez na Capela da Misericórdia de Lisboa, no ano de 1655. Vieira proferiu o sermão diante de D. João IV e sua corte, juízes, ministros e conselheiros. Nele Vieira destaca e critica a maneira como alguns políticos exercem o seu poder. Ataca com conhecimento de causa aqueles que usam o poder e o dinheiro público para enriquecer ilicitamente. Vieira aponta ainda para os escândalos, desmandos, fraudes, ou seja, toda a gama de corrupção que envolvia o poder, discorrendo sua visão crítica a respeito do comportamento imoral da nobreza da época.

Suponho finalmente que os ladrões de que falo não são aqueles miseráveis, a quem a pobreza e vileza de sua fortuna condenou a este gênero de vida por que a mesma sua miséria, ou escusa, ou alivia o seu pecado, [...]. O ladrão que furta para comer, não vai nem leva ao inferno: os que não só vão, mas levam, de que eu trato, são outros ladrões de maior calibre e de mais alta esfera; os quais debaixo do mesmo nome e do mesmo predicamento distingue muito bem São Basílio Magno. Não só são ladrões, diz o santo, os que cortam bolsas, ou espreitam os que se vão banhar para lhes colher a roupa; os ladrões que mais própria e dignamente merecem este título são aqueles a quem os reis encomendam os exércitos e legiões ou o governo das províncias, ou a administração das cidades, os quais já com mancha, já com forças roubam cidades e reinos: os outros furtam debaixo do seu risco, estes sem temor nem perigo: os outros se furtam, são enforcados, estes furtam e enforcam (VIEIRA, 1968, p. 32).

O enfoque de Vieira baseia-se nos erros e nos abusos cometidos pelos representantes do poder. O sermão apresenta uma visão crítica sobre o comportamento imoral da nobreza da época, sobretudo os escândalos do governo, as riquezas ilícitas, as 
venalidades de gestões fraudulentas e a desproporcionalidade das punições do século XVII. É destaque nesse sermão a dimensão de seu propósito e a eloquência com que foi proferido, visto que Vieira estava diante de quem representava o poder. Isso, no entanto, não o impediu de instigar, apontar, criticar e defender a quem necessitasse.

Nessa mesma visada crítica, segue-se o Sermão da Sexagésima, proferido na Capela Real, em 1655, a um auditório constituído em grande parte por pregadores dominicanos, que eram inimigos dos jesuítas, e católicos da nobreza portuguesa.

Considerado um dos seus mais importantes sermões, Vieira o prega com base na Parábola do Semeador (MATEUS, 13: 1-9 e 19-23). No Sermão da Sexagésima, Vieira argumenta sobre a arte de pregar / a eloquência de alguns pregadores, provocando-os a pensar sobre sua culpa pelo pouco efeito da palavra de Deus nos fiéis. Vieira critica os sermonistas que praticam o cultismo, com textos calcados mais na exaltação literária, deixando em segundo plano seu caráter de reflexão existencial e religiosa. Vieira mais uma vez utiliza seus sermões para criticar aqueles que, segundo ele, usavam seus poderes / seus dons com má fé.

Além dos sermões, Vieira utilizou as cartas como recurso para se comunicar com autoridades de seu tempo e denunciar diversas situações, entre elas, as questões relativas à autonomia das missões jesuíticas, os problemas indígenas no Brasil, o governo colonial brasileiro, as demais ordens religiosas e as questões envolvidas no processo movido contra ele pelo Tribunal do Santo Ofício de Coimbra, sob alegação de vários crimes de heresia, especialmente, o de judaísmo.

Do conjunto de cartas escritas por Vieira, destaca-se a Carta Ânua da Província do Brasil, escrita em língua latina, por ordem do Provincial da Bahia ao Geral da Companhia, que relata as ocorrências dos anos de 1624 e 1625, quando a cidade da Bahia estava sob ataque holandês. Destaca-se também a carta conhecida como Esperanças de Portugal, V Império do Mundo, de 29 de abril de 1659, por ocasião da morte de D. João IV, dirigida ao Padre André Fernandes. Essa carta rendeu-lhe consequências funestas, uma vez que se tornou a base da qualificação dos crimes que lhe foram imputados pelo Tribunal do Santo Ofício de Coimbra. O texto a seguir é um trecho da Carta Anua, em que Vieira descreve o desembarque dos holandeses em Salvador:

Com uma companhia de eclesiásticos, armados não só para animar a gente, mas para com a espada na mão se defender, e ofender se fosse necessário, ao inimigo. E correndo todas as estâncias, exortava a todos como verdadeiro prelado, e pastor, a pelejarem até a morte por sua Fé e Rei, e que vencendo ou morrendo por esta causa sempre venceriam. Saíram com a mesma pressa os nossos soldados, e o mesmo fizeram muitos dos outros religiosos. Prepararam-se com não menor cuidado as almas para morte que os corpos para a guerra [...] (VIEIRA, 2003, p. 82-83).

Grande defensor dos judeus, Vieira considerava a perseguição desse povo uma injustiça que contrariava as leis divinas e humanas. De acordo com Besselar (1981, p. 22),

Defender os judeus, tal como Vieira os defendia, era um acto de bom senso, mas também um gesto corajoso e perigoso no ambiente mesquinho em que vivia. Seria injusto acusálo de oportunismo, pois a defesa dos judeus, constantemente retomada, havia de custarlhe o ódio dos inquisidores e a suspeita dos fanáticos. Sem dúvida, o jesuíta julgava que 
revocar os judeus era uma medida de sã economia, e mantê-los fora do país revelava uma miserável pobreza de espírito.

Por diversas vezes, Vieira procurou recorrer às autoridades, a fim de pacificar a situação. A defesa dos cristãos novos e a sua fidelidade ao rei valeram-lhe o ódio da Inquisição.

Especialmente por suas prédicas a favor dos cristãos novos, foi perseguido, sendo preso pela Inquisição em 1665 e depois mantido em custódia. Foi interrogado inúmeras vezes, perdendo o direito de falar ou escrever sobre algumas matérias. Após pregar vários sermões que lhe deram notoriedade em Roma, defendendo os cristãos novos, foi louvado pelo Papa, que o isentou da Inquisição em 1675. Vieira passou os últimos anos de sua vida na Bahia, organizando suas obras. Morreu em 1697, aos 89 anos.

Estamos diante de um homem do século XVII, acostumado a veicular sua crença, seus propósitos, por meio de atitudes estruturadas na e pela palavra, conseguindo com ela romper preceitos muitas vezes já concretizados a exemplo do processo inquisitorial. Os autos de fé eram espetáculos repletos de emoções, não sendo fácil desenvolver paralelamente outra linguagem que respondesse a esse tipo de encenação. Daí que Vieira precisou arquitetar um discurso político e teológico habilmente elaborado. "Retóricas múltiplas, casuísmos infindáveis que disputam o monopólio do discurso verdadeiro, pretendendo todas as exclusividades da fundamentação da Potência Soberana" (HANSEN, 1978, p. 178). Vieira demonstra seu estilo alegórico de interpretação bíblica, por meio do jogo de ideias e de conceitos, num tom persuasivo que segue um raciocínio lógico, capaz de materializar na exposição dos fatos as razões que acompanham cada argumento. Utiliza a seu favor explicações conclusivas, baseadas na história da humanidade e em textos bíblicos, com a finalidade de captar melhor o entendimento do leitor, mas sobretudo para (de) marcar a verdade de seus planos.

A palavra, dentro da estrutura retórica, pode desencadear um processo de reflexão intenso, confluindo para o aprimoramento dos efeitos do pensamento. De acordo com Alcir Pécora (2008, p. 206),

[...] o que se vê, na obra de Vieira, é uma unidade retórico-político-teológica, em que todos os temas estão unidos sob a mesma égide, que se funda na constatação da onipresença divina no mundo e na necessidade, por exemplo, de a política ser feita sob uma base teológica.

Para isso, Vieira organizou seu discurso por meio da parenética. A parenética refere-se à eloquência sacra. Os jesuítas em suas missões de catequese utilizavam-se dela para a aproximação com seu "público". De modo geral, o pregador inicia sua fala pelo prólogo, que é dividido em tema, intróito e invocação. Na sua apresentação, pede auxílio aos céus para o adequado tratamento do tema, ressaltando a escolha da passagem bíblica na qual será baseada a pregação. Na sua argumentação, o pregador apresenta os exemplos bíblicos e insere argumentos que fundamentam seu pensamento. Isso se faz com a intenção de persuadir os ouvintes acerca de suas ideias.

A lógica com que Vieira encaminha seu discurso possibilita conclusões em favor de suas proposições, por meio de um discurso que quer desorganizar a percepção do público. Viera soube aproveitar bem o momento, a ocasião, que de certa forma favoreceu 
a propagação de seus ideais político-religiosos. Assim, firmou sua percepção política do mundo com base e por vias de princípios teológicos.

Temos então o cruzamento das várias faces de Vieira como representante da cultura luso-brasileira: o pregador inspirador, o jesuíta controverso, o político habilidoso, o homem público que estava acima das vertentes do tempo e da religião. E, além disso, um homem de ação.

Dessa forma, o que nos foi possível escrever sobre a vida de Vieira é pouco diante da figura representativa de uma época que ele foi. Suas ações, suas ideias e seu modo de viver redigiram as principais facetas de sua vida. Os ataques de Vieira aos senhores de escravos, a cobrança de obediência às determinações de Lisboa quanto à liberdade indígena por parte dos governantes e capitães-mor, a acepção de outras ordens religiosas, que foram fatores para a expulsão de Vieira do Brasil, tudo isso nos ajuda a compreender o que Vieira representou na construção de uma ideia de brasilidade, trilhando os caminhos que lhe eram possíveis na época. Ao mesmo tempo, podemos começar a entender a complexidade do aparato colonial e a rejeitar explicações simplistas e limitadas que apontam somente para a aliança entre metrópole, colônia e igreja católica.

\section{A personagem António Vieira}

No romance Boca do Inferno, Ana Miranda representa Padre António Vieira como homem de comportamentos dominados pela razão, capaz de se posicionar e representar o povo. Na obra de Miranda, Vieira já está idoso, tempo em que ficou retirado na Quinta do Tanque, na Bahia, elaborando seus sermões. Suas ideias, seus comportamentos são organizados mediante um conjunto, que passo a passo são delineados no decorrer da trama sob a ótica observadora de um narrador que traz à tona acontecimentos indispensáveis na formação da personalidade de Vieira enquanto personagem fictícia e personagem histórica comprometido com o contexto em questão.

Hoje em dia é assim: um moço sem pai, mal herdado da natureza, sem valor para seguir as armas, sem engenho para cursar as letras, moço sem talento, nem indústria para granjear a vida por outro exercício. É desonesto? Vai governar? [...] Continuaria a pensar na improbidade dos homens. (MIRANDA, 2007, p. 61).

O fato de Vieira aparecer como um idoso no romance não retira suas características de filósofo e de político tal como ele foi, especialmente no que diz respeito aos problemas que envolviam a forma como era governada a Bahia e, por extensão, o Brasil colônia. Ele criticava aqueles que de forma corrupta dirigiam o poder na colônia.

Teles de Menezes conjugava o verbo furtar e odiar em todos os tempos. Um cão mandativo, um abominador optativo, um perverso conjuntivo, um salafrário infinitivo. Marco Varro dizia que os que serviam ao lado dos reis eram os laterones. Mas depois passaram a ser os ladrones. Vão todos de mãos dadas para o inferno. Os magnetes atraem o ferro, os magnetes atraem o ouro. Perde-se o Brasil nas unhas escorregadias dos governantes. O povo daqui sofre por uma ralé ignorante. Os pobres cabritos de Deus, esses vão para o céu (MIRANDA, 2007, p. 58). 
Vieira é acusado, no romance, de participar do assassinato do alcaide-mor Francisco Teles de Menezes, crime que desperta a ira dos poderosos, liderados por Antonio de Souza Menezes, que passa a perseguir os supostos culpados, que fariam parte de um grupo liderado pelo próprio Vieira.

Vieira é apresentado como orador sacro, participante de vários acontecimentos importantes na cidade de Salvador. Era irmão e tio de envolvidos no assassinato do alcaide-mor, além de esconder os culpados no Colégio dos Jesuítas e ser o responsável também pela fuga de conspiradores. Também a sua personalidade e a sua oratória foram diversas vezes afrontadas pelo governador publicamente: '[...] tinham sido públicas as afrontas ao jesuíta.' (MIRANDA, 2007, p. 287).

Vieira continua a escrever cartas para seus correspondentes na Europa, "Cartas a fidalgos, ministros e validos, intrigando contra o Braço de Prata e o alcaide Teles." (MIRANDA, 2007, p. 179), enviando seus sermões para lá, relembrando sua vida como missionário e defensor dos indígenas e dos judeus / dos cristãos novos, além de ter sido perseguido pela Inquisição. Sua vida anterior é retratada por meio da memória da personagem.

Viviam os cativos em péssimas condições, ocupados nas cruéis lavouras de tabaco; não tinha tempo de trabalhar suas roças nem recebiam alimentos, com o que eles, suas mulheres e filhos padeciam e pereciam de fome [...] Vieira não queria mais pensar naquilo, porém eram lembranças que sempre o atormentavam. Lutara para cerrar os sertões e proibir para que não houvesse resgates, e para que fossem declarados livres todos os resgatados (MIRANDA, 2007, p. 42).

No plano de vingança do governador Menezes pela morte do alcaide-mor, Vieira é perseguido, porém, por representar a Igreja Católica e o poder papal, não é preso. Por outro lado, seu irmão, Bernardo Ravasco, é preso e destituído do cargo de Secretário do Estado.

Em 1696, Vieira ficou cego e parcialmente surdo, tendo que ditar cartas a José Soares, que as redigia. Antes de morrer, Vieira enviou uma circular à nobreza de Portugal, despedindo-se. Morreu no verão de 1697: “O barco que, no verão de 1697, levou ao reino a notícia de sua morte transportava ainda cartas suas" (MIRANDA, 2007, p. 298).

Na obra A Personagem de Ficção, lemos: "[...] é a personagem que com mais nitidez torna patente a ficção, e através dela a camada imaginária se adensa e se cristaliza" (CANDIDO, 2002, p. 21). A personagem funciona como um elo que sustenta o discurso ficcional da narrativa, transpondo para ela a voz do autor, que aborda de maneira significativa as observações e as virtudes experimentadas e assim definidas, a fim de serem projetadas no discurso por meio das personagens. Sobre o mesmo tema, Reis e Lopes (2000, p. 215) consideram a personagem uma categoria fundamental da narrativa.

A personagem evidencia a sua relevância em relatos de diversa inserção sociocultural e de variados suportes expressivos. Na narrativa literária (da epopéia ao romance e do conto ao romance cor-de-rosa), no cinema, na história em quadrinhos, no folhetim radiofônico ou na telenovela, a personagem revela-se, não raro, o eixo em torno do qual gira a ação em função do qual se organiza a economia da narrativa.

Percebemos o domínio que a personagem desempenha em uma narrativa, como isso se configura e o sentido que esse discurso tem para os leitores. $\mathrm{Na}$ obra de ficção, 
cada personagem ocupa um lugar específico em cada formação social. Entretanto, há personagens que ocupam o eixo do poder político, do poder eclesiástico e do poder econômico, produtores de características internas e externas do enredo em questão. $\mathrm{O}$ lugar ocupado por Vieira no romance Boca do Inferno prolifera sentidos que agregam valores importantes à narrativa romanesca, presumindo-se também que se trata de um romance histórico. Assim, o eixo que Vieira ocupa ultrapassa os limites da ficção sem deixar de ser ficção, dado o valor que o romance histórico contemporâneo agrega aos enredos históricos.

De igual importância dentro da ficção, está a maneira como a personagem nos é apresentada. Vieira surge pela voz de um narrador observador em terceira pessoa que, por meio de seu discurso indireto livre, mistura-se com o pensamento da personagem, trazendo à tona as recordações de Vieira e os sofrimentos que elas lhe trazem: "Viviam os cativos em péssimas condições, ocupados nas cruéis lavouras de tabaco [...] suas mulheres e filhos padeciam de fome [...] Vieira não queria mais pensar naquilo, porém eram lembranças que sempre o atormentavam" (MIRANDA, 2007, p. 49).

A construção da personagem deve-se muito às recordações de Vieira. É por meio da memória de Vieira que conhecemos seu passado, portanto sua história que dá corpo a sua personagem. Pensando nesse aspecto, compreendemos que a sua representação parte de uma memória que pode ser falha pela dificuldade de atribuir com exatidão as notas que se têm do passado que é uma imagem que perpassa rapidamente, como também é subjetiva. Portanto lidamos com recortes e seleções de recordações. Vieira enquanto personagem é uma construção que se firma por um discurso, talvez inconcluso, pois não podemos saber com exatidão o que aconteceu. Isso revela o cuidado e a consciência de Ana Miranda enquanto autora, principalmente de um romance histórico, em criar, em matéria de discurso, uma personagem que enquanto sujeito histórico se esboçou quase que por semelhantes vias. Conhecemos da personagem Vieira no romance o que o seu discurso nos permite conhecer, assim como na história a persona Vieira é criada pelas suas próprias impressões registradas em suas correspondências e textos de caráter autobiográfico ou nos tomos da Defesa Perante o Tribunal do Santo Oficio, em que Vieira é apresentado por ele mesmo. O romance estabelece por esse e outros critérios a verossimillhança necessária ao seu entedimento. $\mathrm{O}$ discurso ficcional se elabora por elementos próprios sem estar alheio ao que já é firmado de tal personagem.

É por vias das recordações de Vieira que o discurso do narrador firma-se e constrói a imagem do orador sacro, do político irreverente, que se contrapõe ao discurso do governador da cidade e, consequentemente, ao poder político vigente. Dentro da teoria da narrativa, esse recurso utilizado pela voz narradora é chamado de analepse. A analepse, de acordo com o Dicionário de Teoria da Narrativa, corresponde a todo "[...] movimento temporal retrospectivo destinado a relatar eventos anteriores ao presente da ação e mesmo, em alguns casos, anteriores ao seu início" (REIS; LOPES, 2000, p. 230). Percebemos, assim, que por meio das analepses o narrador esclarece fatos passados da vida de Vieira e que são de grande importância na construção da personagem no tempo presente da narrativa, especialmente no que diz respeito à sua trajetória em defesa dos perseguidos e dos escravizados pela metrópole portuguesa, a exemplo dos judeus / dos cristãos novos e dos índios. Nós, leitores, só temos acesso a essas informações graças a essa retomada de fatos anteriores. 
'Ah, quem pudera desfazer o passado, e tornar atrás o tempo e alcançar o impossível, que o que foi não houvera sido'. Olhando aquele menino índio, Vieira lembrou-se de seus infortúnios no Maranhão (MIRANDA, 2007, p. 41).

[...] em, talvez eu possa ajudar, afinal estou neutro e tenho, assim como vós, amigos no governo, apesar de judeu e perseguido [...] Não posso me esquecer do quanto devemos a vossa atuação e a vossa inteligência quando da criação da Companhia Geral do Comércio para o Brasil, que foi para nós um grande benefício, mais ainda, um duro golpe na Inquisição, nossa velha inimiga, que deixou de recolher o confisco de nossos bens para, com nosso próprio dinheiro, nos queimar em fogueiras nos suntuosos autos-de-fé. (MIRANDA, 2007, p. 166).

A constituição da personagem Vieira é fortemente marcada pelo discurso romanesco, que tematiza a narrativa, aliado ao discurso político e religioso do padre, com destaque para a linguagem utilizada nos sermões proferidos em diversas situações do romance. Todos esses acontecimentos são organizados em face dos acontecimentos políticos do governo de Antonio de Souza na Bahia e em função da intriga que envolve Vieira no assassinato do alcaide Teles de Menezes, sendo a culpa atribuída à família Ravasco.

É compreensível à autora o fato de ter como recurso o discurso histórico, exercendo papel de relevância na narrativa. Boca do Inferno, na qualidade de romance histórico, que tem como protagonistas dois nomes reconhecidos da literatura e da história brasileiras, o já anunciado António Vieira e o poeta Gregório de Matos, possibilita a arquitetura do projeto estético estabelecido por Ana Miranda. A autora, recorrendo à representação historiográfica, introduz em seu discurso a biografia e as obras dessas personalidades da vida literária brasileira, produzindo um mapeamento da história e da vida política e cultural do País entre os séculos XVI e XX, o que justifica ser o romance Boca do Inferno uma forma de reinterpretação do passado, bem como uma reflexão sobre a literatura.

Tendo a posse dessa informação, é possível discutirmos a presença dos sermões de Vieira que contribuíram para a constituição da personagem. Soma-se a isso o valor dos sermões na propagação dos ideais da vida do Padre enquanto ser histórico, os valores por ele disseminados, o teor de seus sermões e o contexto em que ele os produziu. No romance, os sermões são apresentados por meio de sua apropriação pelo narrador, que faz uso da paráfrase, a fim de transmitir a mensagem ao leitor. "Nossos homens públicos são ou contemplativos ou ladrões. Roubar uma moeda faz um pirata, roubar uma cidade e seus palácios faz um Alexandre" (MIRANDA, 2007, p. 58). Esse discurso é uma apropriação do Sermão do Bom Ladrão de Vieira, que o narrador modifica a sua maneira, porém mantém firme o propósito do sermão em criticar os que exercem o poder de forma corrupta.

Os ladrões que mais própria e dignamente merecem este título são aqueles a quem os reis encomendam os exércitos e legiões ou o governo das províncias, ou a administração das cidades, os quais já com mancha, já com forças roubam cidades e reinos: os outros furtam debaixo do seu risco, estes sem temor nem perigo: os outros se furtam, são enforcados, estes furtam e enforcam (VIEIRA, 1968, p. 32). 
Algumas conversas de Vieira na obra, especialmente com o seu irmão Bernardo Ravasco, são trechos de seus sermões que foram direcionados pela voz narrativa, a fim de ter o efeito adequado à obra. Temos, por exemplo, a fala de Vieira ao tomar conhecimento de que Braço de Prata, o governador, juntamente com sua milícia, invadira casas, as saqueara e queimara-as à procura dos supostos criminosos do assassinato do alcaide-mor, valendo-se de algumas palavras de seu Sermão pelo Bom Sucesso das armas de Portugal contra as de Holanda (1640), a fim de demonstrar a sua repulsa:

Para isso foi que abrimos os mares nunca dantes navegados? Para isso descobrimos as regiões e os climas não conhecidos? Para isso contrastamos os ventos e as tempestades como tanto arrojo...? (MIRANDA, 2007, p. 54).

Para que abrimos os mares nunca dantes navegados? Para que descobrimos as Regiões e os climas não conhecidos? (VIEIRA, 2007, p. 451).

O Sermão pelo Bom Sucesso das armas de Portugal contra as de Holanda foi pregado na Igreja de Nossa Senhora da Ajuda, na Bahia, tendo como intuito persuadir os colonos portugueses e mesmo os índios a resistirem e a lutarem mais contra os holandeses que haviam invadido a Bahia em 1640. No romance, esse sermão foi recontextualizado, de forma que podemos entender que Vieira sugere uma semelhança entre o governador Antônio de Souza e sua polícia com os hereges holandeses, que também saquearam a Bahia.

O narrador faz a apropriação, ainda, de outros sermões, como o Sermão do Bom Ladrão, pregado em 1655 perante D. João IV e sua corte: "Nossos homens públicos são ou contemplativos ou ladrões" (MIRANDA, 2007, p. 67), e o Sermão da Terceira Dominga da Quaresma: "Dize ao príncipe que [...] precisamos de homens que obrem proezas dignas de seus antepassados [...] E não homens que nos aproveitam e nos arruínem" (MIRANDA, 2007, p. 213).

Sabemos que o padre Vieira é uma personagem histórica no contexto da historiografia brasileira e da portuguesa e literária na obra de Ana Miranda. Porém, dentro da narrativa e desta discussão, trata-se de um ser ficcional que carrega em si todos os elementos de uma construção imaginária. Todo discurso utilizado na formação da personagem, por mais semelhante que seja ao histórico, é um discurso ficcional.

Em Boca do Inferno, o narrador em terceira pessoa delega o ponto de vista ao personagem Vieira em situações extremas, a fim de projetar uma visão conjunta da personagem e assim representar a sociedade em questão, bem como os desejos e a missão do padre, os anseios do povo, a ganância de muitos pelo poder e a denúncia em torno da situação pela qual o espaço social passava.

Bastante favorável a essa questão, consideramos ainda a liberdade que a personagem ficcional pode assumir dentro da narrativa. $\mathrm{O}$ ser ficcional corresponde ao projeto de entidade que circula livremente dentro da obra, tendo em vista que pode se colocar em diferentes posições com propriedade e congruência. Ela pode adquirir uma grande variedade de características que se associam com um grau de fantasia elevadíssimo, determinante de infinitas ações e de inúmeras significações dentro do contexto textual. 
Precisamente pelas limitações das orações, as personagens têm maior coerência do que as pessoas reais (e mesmo quando incoerentes mostram pelo menos nisso coerência); maior exemplaridade (mesmo quando banais) [...] maior significação; e paradoxalmente, também maior riqueza - não por serem mais ricas do que as pessoas reais, e sim em virtude da concentração, seleção, densidade e estilização do contexto imaginário, que reúne os fios dispersos e esfarrapados da realidade num padrão firme e consistente (CANDIDO, 2002, p. 35).

Notamos que as pessoas reais se constituem de unidades concretas com funções limitadas. São seres humanos individuais e assim como a realidade em geral a visão que temos deles é extremamente fragmentada e restringida. Tal restrição não favorece as múltiplas resoluções que envolvem o ser real. Não as vemos por inteiro, as vemos parcialmente, o que não permite o teor de significado absoluto da nossa visão. Além disso, toda essa gama de sentidos e de valores que temos por meio da personagem deve-se à linguagem utilizada nessas diferentes situações, possibilitando também diferentes significados oferecidos somente pelo texto ficcional.

Vieira representa o universo romanesco enquanto ser histórico e ficcional. O narrador narra a trama da ótica de quem observa com a função de também opinar, revelando seu posicionamento diante das situações em questão e por isso se vale do discurso histórico, a fim de tornar coerente a sua intenção e, consequentemente, a função da narrativa. Para tanto delega a voz, como já dito, à personagem que, no caso de Vieira, é histórica, composta de caráter político e religioso, o que credencia o seu discurso, dado o valor de quem é autorizado a difundir os ideais e os discernimentos propícios ao momento. Isso acontece graças à estrutura da ficção, à sua coerência interna, à sua lógica inerente. Assim, temos no romance as conversas de Vieira com seu irmão Bernardo Ravasco, que aos poucos evidenciam a caracterização de Vieira e a representação dos conflitos existentes, bem como a relação de Vieira com os inimigos que estavam diante do poder:

'Ah irmão', disse Bernardo Ravasco, ' não tens tantos inimigos assim. És mais amado que odiado.' Que mais ingênuo tu és. Eles me odeiam pois não sou um solitário de Tebaida, estou aqui me matando para não ter certeza de salvar a alma de ninguém, nem mesmo a minha', disse Vieira. "Tens teu lugar garantido no céu".'Detesto as litanias fastidiosas. Não sou um daqueles sacerdotes de perna peluda celebrando a missa com cálice de cornos de touros.' 'Entendo irmão. Mas como estão indo os escritos dos sermões?' disse Bernardo Ravasco tentando trazer um assunto mais ameno (MIRANDA, 2007, p. 57).

Em Boca do Inferno, Vieira nos é apresentado à luz do passado, que é mostrado para o leitor por meio das memórias do próprio Vieira, memórias estas que são costuradas com o momento da enunciação, sendo válida na construção do sentido da narrativa. $O$ fato de Vieira aparecer como um idoso no romance não o isenta das características inerentes à sua projeção no meio em que esteve inserido. Essa projeção resulta na formação de uma personagem que assume, dentro da narrativa, uma posição desencadeadora de muitas ações e reações e decidindo seu entrecho final. O Vieira romanesco, que está na Quinta do Tanque ordenando seus escritos, seus sermões, rememora as lembranças de sua vida de missionário, de privado de reis, de defensor de índios e da causa judaica / cristã nova, de perseguido pela Inquisição. O processo de rememoração acontece com o objetivo de estabelecer uma continuidade entre o tempo em 
que os sermões foram pregados para uma plateia de fiéis ouvintes e o tempo em que foram reescritos para uma posteridade de leitores.

A representação de Vieira criada pelo romance mostra ao leitor um homem dominado pela razão, com um passado marcado por boas e más ações e também por sofrimentos. Um grande orador, mobilizador da sociedade e, acima de tudo, um porta voz da população diante da situação de caos por que passava a sociedade diante das autoridades metropolitanas.

Pensar nos aspectos que envolvem a construção de Vieira em Boca do Inferno, de Ana Miranda, desde o embasamento histórico no qual ele foi constituído até sua representação ficcional, permite inferirmos que a construção da personagem se deve aos elementos inerentes à narrativa ficcional, bem como ao discurso romanesco, e ainda à apropriação por parte do narrador do discurso histórico, incluindo os sermões, tudo isso articulado de maneira a representar o contexto sociopolítico e cultural no qual a personagem está imbricada. Como protagonista, ele reúne em si boa parte das comandas cruciais e relevantes no desencadear da narrativa. A composição dessa representação está centrada na relação do objeto temático com as referências exteriores de tempo e espaço.

Naquele dia inteiro e no dia seguinte Vieira ainda continuaria a toda a velocidade, não teria dormido mais que três horas durante a noite pensando na improbidade dos homens, para ter mais uma cascata tormentosa de deprecações sempre bem fundadas. Tomás de Aquino, São Paulo, a Bíblia inteira para comprovar suas teses (MIRANDA, 2007, p. 61).

Ana Miranda caracteriza Vieira em sua forma física, psicológica e cultural de modos diversificados no decorrer da narrativa:

Depois de alguns instantes apareceu Antonio Vieira pela porta lateral. Trajava um simples hábito que já fora negro, amarrado à cintura por uma corda fina. Trazia na mão direita uma pena como se estivesse parado de escrever naquele momento (MIRANDA, 2007, p. 39).

Naquele tempo andava vestido de um pano grosseiro fabricado na região, preto desbotado: comia farinha-de-pau, dormia pouco; léguas e léguas eram vencidas a pé, não havia por aquelas partes nenhum gênero de montaria (MIRANDA, 2007, p. 41).

As descrições revelam o comportamento de Vieira na dinâmica dos acontecimentos. Na primeira descrição temos a caracterização da primeira aparição de Vieira no romance. Estavam todos reunidos na igreja, os padres, o irmão de Vieira, na ocasião em que ocorre o assassinato do alcaide-mor Francisco Teles de Menezes. Vieira aparece e os irmãos abraçam-se e então ficam sabendo do ocorrido. Na segunda descrição, não tão distante da primeira, temos a imagem de Vieira pelo seu fio de memória, que traz à tona o tempo em que vivia como missionário no Maranhão e sua luta pela liberdade dos índios.

Nas descrições, o narrador coloca paralelamente aspectos que revelam a aparência, os trajes, sem deixar de fixar o caráter psicológico do Padre. Além disso, ambas as descrições revelam o posicionamento de Vieira diante dos acontecimentos. O Vieira de anos atrás, na luta pela liberdade indígena, permanece solidário diante da nova luta em que ora mergulhava, a luta contra os desmandos da Bahia colonial, bem como contra a soberania do governo tirânico de Antônio de Souza Menezes. 
O Vieira ficcionalizado, já idoso, também intensifica a voz da narrativa, idealizado pelo propósito de Ana Miranda. Vieira resume os anos vividos no tocante a sua chegada ao Brasil, sua entrada no colégio dos jesuítas, seus trabalhos na Companhia de Jesus como missionário, sua luta em defesa dos indígenas, dos judeus / dos cristãos novos. Suas conversas, suas ideias e o valor delas enriquecem o teor da relação que Vieira mantém com o grupo de conspiradores e, assim, possibilitam a ação dos envolvidos no contexto que resultou na intervenção dos problemas em questão.

A presença de Vieira teve o êxito que a formação e a maturidade lhe permitiram. $\mathrm{O}$ valor da sua maturidade corresponde ao propósito estabelecido em difundir a personagem como idoso na obra. A voz narradora não deixou que tal façanha passasse despercebida, firmando na constituição da personagem a imagem de um homem bom, coerente em suas atitudes e, portanto, estruturado naquilo que Candido salienta e que já foi mencionado neste trabalho: "É a personagem que com mais nitidez torna patente a ficção, e através dela a camada imaginária se adensa e se cristaliza" (CANDIDO, 2002, p. 21).

Assim, o romance Boca do Inferno apresenta, na figura do Padre Vieira, a bagagem significativa na construção de um contexto que garantiu a ilustração da esfera contextual e psicológica de sua vida. Essa faceta garante o equilíbrio que permite identificar cada ser em questão, no que se refere ao Padre António Vieira ficcional e ao Padre António Vieira da historiografia.

Concluímos que Boca do Inferno demonstra sua relação com o contexto no qual foi produzido ao trazer a história da Bahia colonial, do Brasil, para o romance, num exercício de liberdade que desconstrói e apresenta uma nova história. No tocante à ficcionalização do padre António Vieira, não podemos deixar de mencionar o ser que falou de tudo ou de quase tudo, um ser múltiplo como múltipla é sua obra. Essa performance é uma justificativa que respalda a proposta de Ana Miranda ao representar também o contexto sociopolítico, econômico e religioso do século XVII. Ao pensar em uma nova história, a escritora não só dialoga com o século XVII, mas também com um presente que demanda novas leituras de si e de seus antecessores.

\section{REFERÊNCIAS}

BESSELAR, J. V. D. António Vieira: o homem, a obra, as ideias. Lisboa: Divisão de Publicações, 1981.

CANDIDO, A. et al. A personagem de ficção. 10. ed. São Paulo: Perspectiva, 2002.

ESTEVES, A. R. O romance histórico brasileiro contemporâneo: 1975-2000. São Paulo: Editora da UNESP, 2010.

HANSEN, J. A. Vieira, estilo do céu, xadrez de palavras. In: Discurso. São Paulo, n. 9, p. 173-192, 1978.

HUTCHEON, L. Poética da Pós-modernidade: história, teoria, ficção. Tradução de Ricardo Cruz. Rio de Janeiro: Imago, 1991.

LUKÁCS, G. O romance histórico. Tradução de Rubens Enderle. São Paulo: Boitempo, 2011.

MIRANDA, A. Boca do Inferno. São Paulo: Companhia das Letras, 2007. 
MERQUIOR, J. G. De Anchieta a Euclides: breve história da literatura brasileira. 3. ed. Rio de Janeiro: Topbooks, 1996.

MOISÉS, M. Dicionário de termos literários. São Paulo: Cultrix, 1988.

MURARO, V. F. Padre António Vieira: retórica e utopia. Florianópolis: Insular, 2003.

NEVES, O. Padre António Vieira. Dossiê completo dirigido às escolas. 2010. Disponível em: <http://www.vidaslusofonas.pt/padre_antonio_vieira.htm>. Acesso em: 11 jul. 2012. PÉCORA, A. (Org.). Sermões: Padre António Vieira. 3. reimpr. São Paulo: Hedra, 2003. Teatro do sacramento: a unidade teológico-retórico-política dos sermões de Antonio Vieira. 2. ed. Campinas: Editora da UNICAMP, 2008.

REIS, C.; LOPES, A. C. Dicionário de Teoria da Narrativa. São Paulo: Ática, 2000 [1989].

SARAIVA, A. J. História e Utopia - Estudos sobre Vieira. Lisboa: ICALP, 1992.

VIEIRA, A. Sermões. Organização de Alcir Pécora. São Paulo: Hedra, 1968.

WEINHARDT, M. Considerações sobre o Romance Histórico. Revista Letras, Curitiba: Editora da UFPR, n. 43, p. 49-59, 1994.

Recebido em: 21/08/2016

Aprovado em: 20/07/2017 